\title{
Population dynamics of Cancer polyodon in La Herradura Bay, northern Chile
}

\author{
Matthias Wolff ${ }^{1}$, Marco Soto ${ }^{2}$ \\ ${ }^{1}$ Center for Tropical Marine Ecology, Universitätsallee GW 1/A, W-2800 Bremen 33, Germany \\ ${ }^{2}$ Universidad del Norte, Coquimbo, Casilla 117, Chile
}

\begin{abstract}
The objectives of this study were to assess the density and biomass of a local population of Cancer polyodon in La Herradura Bay, Chile, and to describe its population dynamics: growth (absolute and relative), mortality (natural and fishing) and spawning. Female crabs grew at a higher von Bertalanffy growth rate $(k=0.57)$ but reached a smaller asymptotic size $\left(C W_{\infty}=160.5 \mathrm{~mm}\right)$ than males $\left(k=0.54, C W_{\infty}=198\right)$. A parallel growth study in the laboratory yielded higher $k$ and and lower $C W_{\infty}$ values than for wild specimens and lower values for the growth performance index $\phi^{\prime}$. For both sexes, relative growth (post-moult/pre-moult relationship) was better described by a 2-line model instead of a single 'Hiatt-line'. The intersection of the 2 lines is suspected to mark the onset of gonad formation. Age at massive maturity is ca 2 yr in females and males (at 98 and $124 \mathrm{~mm} \mathrm{CW}$ respectively). Males seem to moult 16 times and females 14 times after the megalopa stage. Spawning occurred over most of the year with pulses in winter and early summer. Average total mortality $(Z)$ was higher in males (2.58) than in females (1.85). A tendency of $Z$ to increase with age indicates that larger specimens are more vulnerable to the traps or have a higher rate of natural mortality $(M)$. $M$ for both sexes was estimated to be between 0.75 and 1.1. Mean annual biomass estimated from Jones' length cohort analysis was 2.4 times and spawning biomass 4 times higher in females than in males. Using the turnover ratio $(Z=P / B)$ an average annual production of $221 \mathrm{~g} \mathrm{~m}^{-2}$ (fresh weight) was estimated from the density data.
\end{abstract}

\section{INTRODUCTION}

Cancer polyodon Poeppig, 1836 (Brachyura: Cancridae) is distributed in the Pacific from Guayaquil, Equador, to the Taitao peninsula, southern Chile (Garth 1959). It is most abundant at 4 to $8 \mathrm{~m}$ depth on heterogeneous sand or muddy sand grounds with refuges of rocks, shells and macroalgae but can also be found in deeper waters (to $25 \mathrm{~m}$ ) and on unstructured sand grounds (Gutierrez \& Zuniga 1976, authors' obs.). It is the largest and most common of the crab species inhabiting the coastal waters of Peru and Chile, where it has been fished by divers and captured with traps for decades. Catches in Chile increased from $1124 \mathrm{t}$ in 1980 to $5138 \mathrm{t}$ in 1987 (SERNAP 1980 to 1987). C. polyodon preys upon clams and scallops (DiSalvo et al. 1984, Mendo et al. 1987. Augsburger \& Vega 1989) and is suspected to be an important regulator for scallop Argopecten purpuratus recruitment (Wolff 1987). Some information exists on its population structure and reproductive cycle in the Bay of Lima, Peru (Talledo \& Ishyama 1988), and on its larval development (Quintana 1981). Despite its value as a local food source and its potential as an export product, no resource evaluation has yet been carried out either in Peru or in Chile and very little is known about its functional role in the shallow water community.

The present study is part of a research programm aimed to assess the population dynamics of Cancer polyodon together with its density and functional role in the shallow water community of La Herradura Bay, northern Chile (Fig. 1). It gives estimates of production and biomass per area, instantaneous rates of growth and mortality, size structure, sex ratio, age at maturity and time of spawning. Most of the da:a were derived from weekly trap catches, some from hand-collected specimens. Two laboratory growth experiments were conducted to compare growth in the laboratory with growth in the natural habitat. 


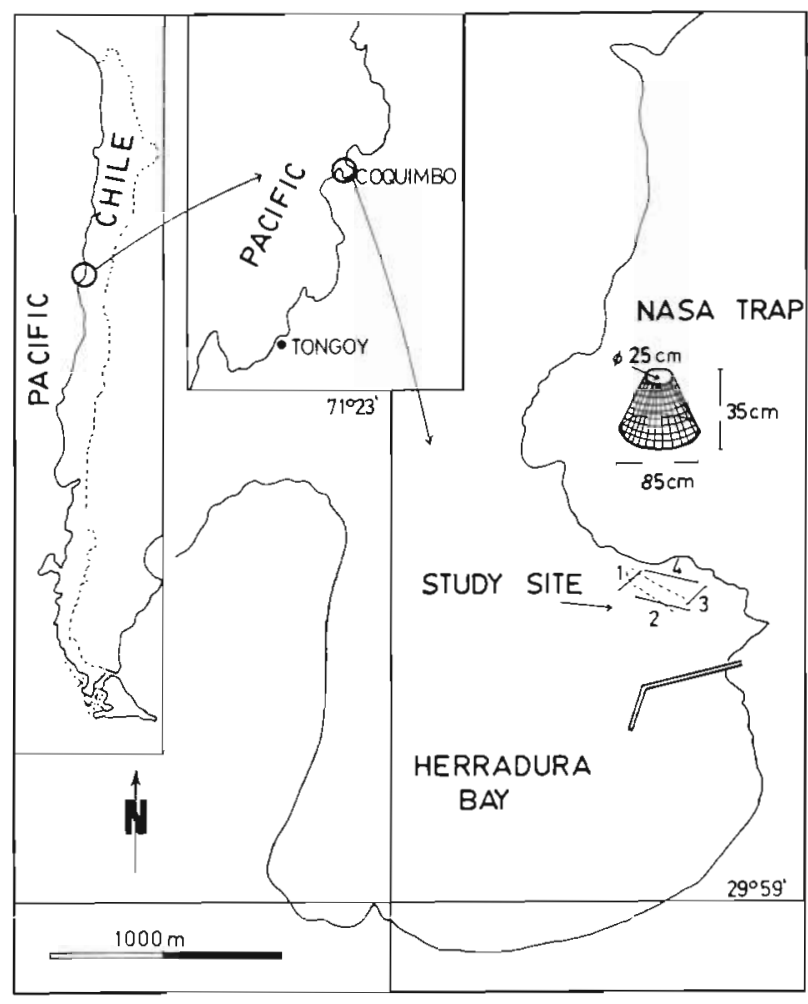

Fig. 1. Study area and trap types used for crab captures. $(-)$ Transects for density estimates; (---) position of traps

\section{MATERIALS AND METHODS}

Sampling, measurements and biometric relationships. Weekly crab catches were made in La Herradura Bay from February 1987 to January 1988 using 'Nasa traps' (Fig. 1). Two parallel lines of 10 traps were placed $6 \mathrm{~m}$ apart at ca $8 \mathrm{~m}$ depth. The traps were baited with sardine or horse mackerel and left for $24 \mathrm{~h}$. Specimens caught were sexed by morphological differences of the abdomen (Gutierrez \& Zuniga 1976). The carapace width $(C W)$ and chela width $(C h W)$ were measured to the nearest $0.1 \mathrm{~mm}$ using calipers and individual wet weight $(W)$ was registered to the nearest $g$. Female crabs were inspected for the presence and maturity (colour) of eggs (Gutierrez \& Zuniga 1976). Relationships between $W$ and $C W$ and between $C h W$ and $C W$ were described by the allometric equation $Y=a X^{b}$, which was log-transformed for analysis $(\log Y=\log a+b \log X) ;$ the resulting regression lines of $C W$ versus $W$ of both sexes were compared statistically by covariance analysis. The plot of $C h W$ versus $C W$ in males was inspected for the existence of 2 distinct allometric phases corresponding to premature and mature specimen (see Fig. 2).

Laboratory growth. Experimental design: Two successive growth experiments with sexes separated were conducted over periods of 7 mo (July 1987 to January 1988 and June 1988 to December 1988). Specimens of 5 to $120 \mathrm{~mm}$ CW were collected by hand in $\mathrm{La}$ Herradura Bay (Fig. 1) and recently moulted (soft shelled) specimens were transferred to the laboratory and kept under observation for $2 \mathrm{~d}$ in $100 \mathrm{l}$ tanks with running sea water. Dead and damaged specimens were discarded. The remaining crabs were placed in six $100 \mathrm{l}$ tanks of running sea water as follows: Eight small specimens ( $\mathrm{CW}: 5$ to $30 \mathrm{~mm}$ ) were put individually into numbered mesh cages of $10 \times 10 \times 15 \mathrm{~cm}$, which were subsequently installed in Tanks 1 and 2 . This experimental design was chosen as preliminary experiments had shown high cannibalism among small individuals when kept in the tank without separation. Eight intermediate-sized specimens ( $C W: 30$ to $50 \mathrm{~mm}$ ) were individually marked with numbered plastic tags glued onto the carapace and were put into Tanks 3 and 4 in groups of 4 crabs each. Tanks 5 and 6 were supplied with 3 marked specimens ( $C W: 50$ to $120 \mathrm{~mm}$ ) each. Every second day, each crab was checked and measured if a moult had occurred. The crabs were fed with a surplus of $20 \mathrm{~g}$ of fish or mollusc flesh every second day. Remaining food was removed prior to subsequent feeding.

Data analysis: As the number of crabs per experiment (22) was low and both experiments were conducted over almost the same months in consecutive years, the data from both experiments were pooled for analysis.

Absolute growth: The average size at each moult (i.e. instar) and the average intermoult period (d) was calculated for male and female specimens. These data were then used as input for a linear regression model developed by Gulland \& Holt (1959) to calculate the von Bertalanffy growth parameters $k$ (instantaneous growth rate) and $L_{\infty}$ (asymptotic size):

$$
\left(C W_{2}-C W_{1}\right) /\left(t_{2}-t_{1}\right)=a-b\left[\left(C W_{1}+C W_{2}\right) / 2\right]
$$

where $C W_{1}$ and $C W_{2}$ are $C W$ at times $t_{1}$ and $t_{2 i} k$ is calculated from the slope of the regression $(k=-b)$ and the asymptotic size (here $C W_{\infty}$ ) from $C W_{\infty}=a / k$. To obtain an estimate for $t_{0}$, the theoretical age at length zero, an age of $85 \mathrm{~d}$ at a size of $3.5 \mathrm{~mm}$ was assumed according to Quintana (1981). These values were then inserted into the reordered von Bertalanffy growth equation:

$$
t_{0}=t+(1 / k) \ln \left(1-C W_{t} / C W_{\infty}\right)
$$

For comparison of the von Bertalanffy growth of Cancer polyodon with that of other crab species, the growth performance index $\phi^{\prime}$ (Pauly \& Munro 1984) was calculated as follows: 


$$
\phi^{\prime}=\log k+2 \log C W_{\infty}
$$

Growth per moult: The Hiatt growth diagram (Hiatt 1948) was used to plot the size at instar $\left(C W_{n}\right)$ against the size at the subsequent instar $\left(C W_{n+1}\right)$ by a least squares regression line. This line was then tested for an inflection point by a technique described by Somerton (1980). The data were repeatedly divided into 2 groups and regressions were calculated for each group. The residual sum of squares of both lines was then summed and the calculation was repeated with another pair of regression lines until the residual sum of squares approached a minimum. An inflection point exists if the pooled residual sum of squares of a pair of the resulting regression lines is significantly lower than the residual sum of squares of a single line. According to Somerton (1980), the test statistic is:

$$
F=\frac{\left(\mathrm{RSS}_{1}-\mathrm{RSS}_{2}\right) / 2}{\mathrm{RSS}_{1} /(n-4)}
$$

where RSS 1 and $\mathrm{RSS}_{2}$ are the residual sums of squares for Models 1 ( 1 line) and 2 ( 2 lines) respectively; $n$ is the number of data points; the statistic is distributed as $F$ with 2 and $n-4$ degrees of freedom.

Field growth. Absolute growth: The $C W$ data of weekly trap catches were pooled into monthly values and subsequently grouped for each sex into size intervals of $12 \mathrm{~mm}$. This relatively wide interval was assumed to be more appropiate because it reduces the possibility of mistaking a moult for an annual mode in the histograms. These data were then analysed using the computer program ELEFAN I (Pauly 1985) that allows for estimation of the von Bertalanffy growth parameters without knowing the age of the individuals. To detect oscillations in the growth rate during the annual cycle, Pauly \& Gaschuetz (1979) incorporated the following extended version of the von Bertalanffy growth equation into the program:

$$
L_{t}=L_{\infty}\left(1-\mathrm{e}^{-k\left\{\left(t-t_{0}\right)+(C k / 2 \pi) \sin \left[2 \pi\left(t-t_{5}\right)\right\}_{1}\right.}\right)
$$

$L_{\ell}, L_{\infty}$, and $k$ are parameters as explained above; $t_{0}$ is the theoretical age at length zero, $\mathrm{C}$ is a constant which represents the amplitude of growth oscillation and $t_{\mathrm{s}}$ is the starting point of the oscillation.

The computation of the growth parameters can be outlined as follows: The length frequency data are first restructured by calculating a running average over 5 length classes and peaks are identified as those parts that are above the corresponding running averages. Von Bertalanffy growth curves are then traced through the length frequency samples for any arbitrary 'seed' input of $k$ and $L_{\infty}$, starting from the basis of each peak and projecting backward and forward in time to meet all other samples of the sample set or the same sample repeated again and again. The curve that passes through the most peaks and avoids the most troughs yields the best parameter estimates.

Growth per moult: For both sexes, all CW measurements during the study period were pooled, grouped into size class intervals of $1 \mathrm{~mm}$, and histograms drawn. These histograms were analysed for their normally distributed components using the method of Bhattacharya (1967). As distributions proved to be unresolvable, the data were regrouped into size intervals of $2 \mathrm{~mm}$, smoothed using a running average over 3 size intervals and reanalyzed with the Bhattacharya method. The above calculation was done assuming that the size at instar was nearly constant throughout the year and that the normally distributed components would represent $C W$ at instar.

Size at first (massive) maturity $\left(C W_{\mathrm{m}}\right)$. Females: In the months of highest incidence of egg-carrying, samples were taken to estimate the size at massive maturity using a method published by Udupa (1986). This method allows the confidence interval for the estimate to be calculated as follows: determination of the proportion of mature females for each size class interval, calculation of the logarithm of the size at first maturity by the formula of Spearman-Karber (as cited in Udupa 1986) and calculation of the confidence limits based on the standard error of the estimate of mean log size (see Table 2 for the calculation procedure).

Males: A plot of $C W$ versus $C h W$ was drawn using all data over the total size range to look for evidence of an abrupt change in relative growth as indicative for maturity (Somerton 1980). As 2 clearly distinct but overlapping phases were detected, the size at massive maturity was calculated as follows: 2 regression lines were calculated using the log-transformed data for each group of data points excluding the points where both lines overlap; the lines in the middle region were extended and the data points were assigned to the line closest to them, thus classifying them as either juvenile or adult (mature); the so classified data of the overlapping region of the graph were grouped into size intervals of $1 \mathrm{~mm}$, and the size at massive maturity was calculated along with its confidence interval using the method of Udupa (1986) as explained above.

Spawning. Egg colour and percentage of egg-carrying females in the trap catches were determined each month. Females with eggs of dark-reddish to beige colour were classified as fully mature and those with yellow-coloured eggs were classified as immature (Gutierrez \& Zuniga 1976).

Total mortality $(Z)$ and natural mortality $(M)$. The same ELEFAN package (Pauly 1985) was used to calculate the instantaneous rate of total mortality via a length-converted catch curve using the same input 
data as were used for the growth analysis. The catch curve was established by plotting the logarithm of the number of individuals in a length class divided by the time needed for an average individual to grow through the length class versus their corresponding relative age. $Z$ was computed from the right descending arm of the catch curve. Rough estimates of the instantaneous rate of natural mortality were obtained by 2 empirical formulas. The first (Rikhter \& Efanov 1976) relates natural mortality $\left(M_{;} \mathrm{Yr}^{-1}\right)$ to the age at first (massive) ma$\operatorname{turity}\left(T_{m}\right)$ :

$$
M=1.521 /\left(T_{\mathrm{m}}^{0.72}\right)-0.155
$$

the second (Pauly 1980) relates $M$ to the growth parameters $k$ and $C W_{\infty}$ and the mean annual water temperature $(T)$ :

$$
\begin{aligned}
\ln M= & -0.0152-0.27955 \ln L_{\infty}+0.6543 \ln k \\
& +0.463 \ln T
\end{aligned}
$$

Population structure, mean annual biomass and density estimates. Histograms of $C W$ data of specimens caught by the diver and captured with the traps were first drawn separately to assess possible selection effects of the traps. For subsequent population analysis, the $C W$ measurements of all trap and diver catches were pooled into 2 yearly samples of males and females, and divided into size-groups of $6 \mathrm{~mm}$. These data were then used as input for Jones' length-based cohort analysis (Jones 1984) as programmed by Sparre (1987). The program was run with 3 different values of $M$ (around the estimated value) and a terminal exploitation rate $(E=F / Z)$ derived from the $Z$-values of the catch curves and the $F$-values $(F=Z-M)$ estimated. In order to estimate the density of Cancer polyodon in the study area, all specimens found on a total area of $600 \mathrm{~m}^{2}$ were collected. To do so, 2 transects of $100 \times 2 \mathrm{~m}$, and 2 of $50 \times 2 \mathrm{~m}$, were marked with lines on the seafloor (Fig. 1). The collection was done simultaneously by 4 divers on 5 May 1987 during the night hours of highest feeding activity of $C$. polyodon (Wolff $\&$ Cerda unpubl.). After sexing and measuring $C W$, the crabs were returned to the sea.

\section{RESULTS}

\section{Biometric relationships}

The $C W \cdot W$ relationship was significantly different between sexes $(F=7.70, \mathrm{p}<0.05)$ :

$$
\begin{array}{lll}
\text { Males: } & W=0.00013 C W^{3096} & (\mathrm{n}=1629) \\
\text { Females: } & W=0.00050 C W^{2.809} & (\mathrm{n}=3079)
\end{array}
$$

The plot of $C h W$ against $C W$ for males showed 2 distinct growth phases for juvenile and mature specimens (Fig. 2).

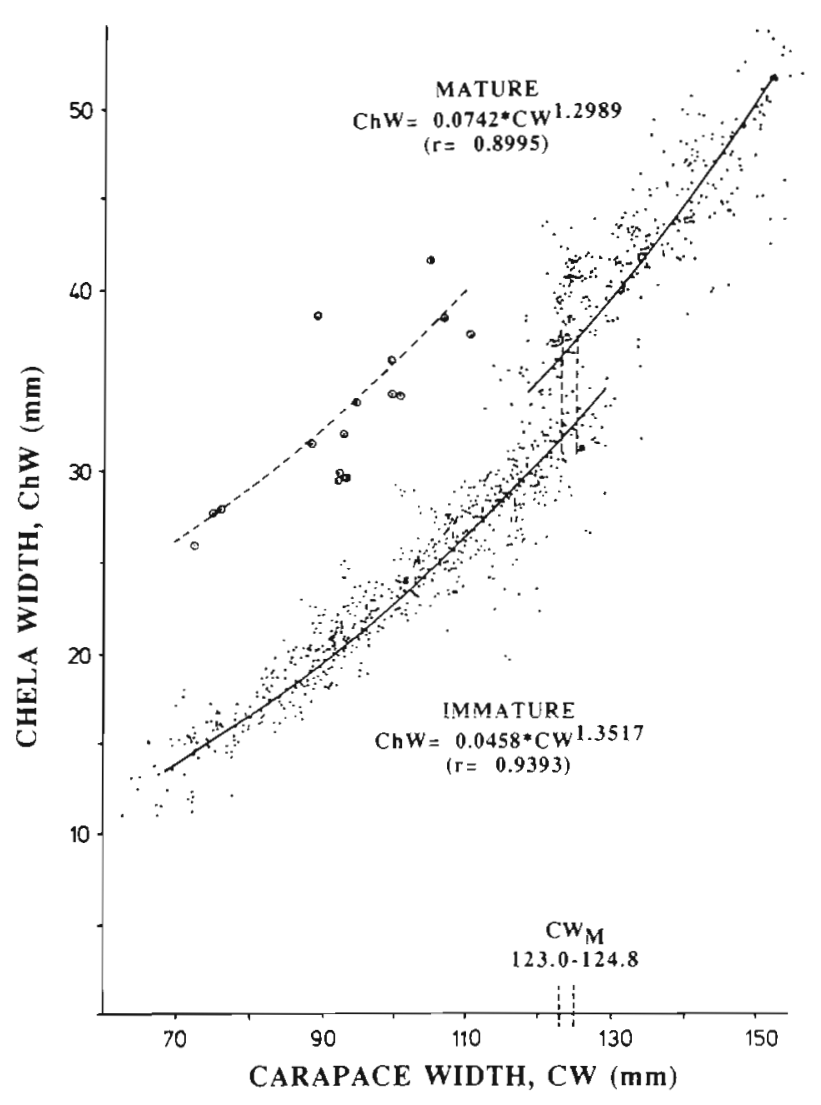

Fig. 2. Cancer polyodon. Carapace width $(C W)$ vs chela width $(C h W)$ for males and estimated confidence limits for size at massive maturity $\left(C W_{\mathrm{m}}\right)$ (for calculation of $C W_{\mathrm{m}}$ see Table 2); (-.--) a group of specimens $<C W_{m}$ with unusually large chelae

\section{Laboratory growth}

Absolute growth. Female growth was slower but statistically not significantly different from males for most of the study period (Fig. 3). For both sexes, the growth rate was highest from instars $5+$ to $6+$; during the subsequent interval (instars $6+$ to $7+$ ) the growth rate slowed down by ca $50 \%$. Over the following moulting periods, the growth rate remained nearly constant (Fig. 3). The Gulland \& Holt plot indicates wide confidence limits for the parameters $C W_{\infty}$ and $k$ for both sexes (Fig. 3). The theoretical age at length zero, $t_{0}$, was estimated as 0.25 using the age of $85 \mathrm{~d}$ at $3.5 \mathrm{~mm}$ CW (Quintana 1981).

Growth per moult. For females and males grown in the laboratory, a 2-line model (see Fig. 4, lines A, B) 
Fig. 3. Cancer polyodon Absolute growth in the laboratory. (- - - ) Females $(-)$ males

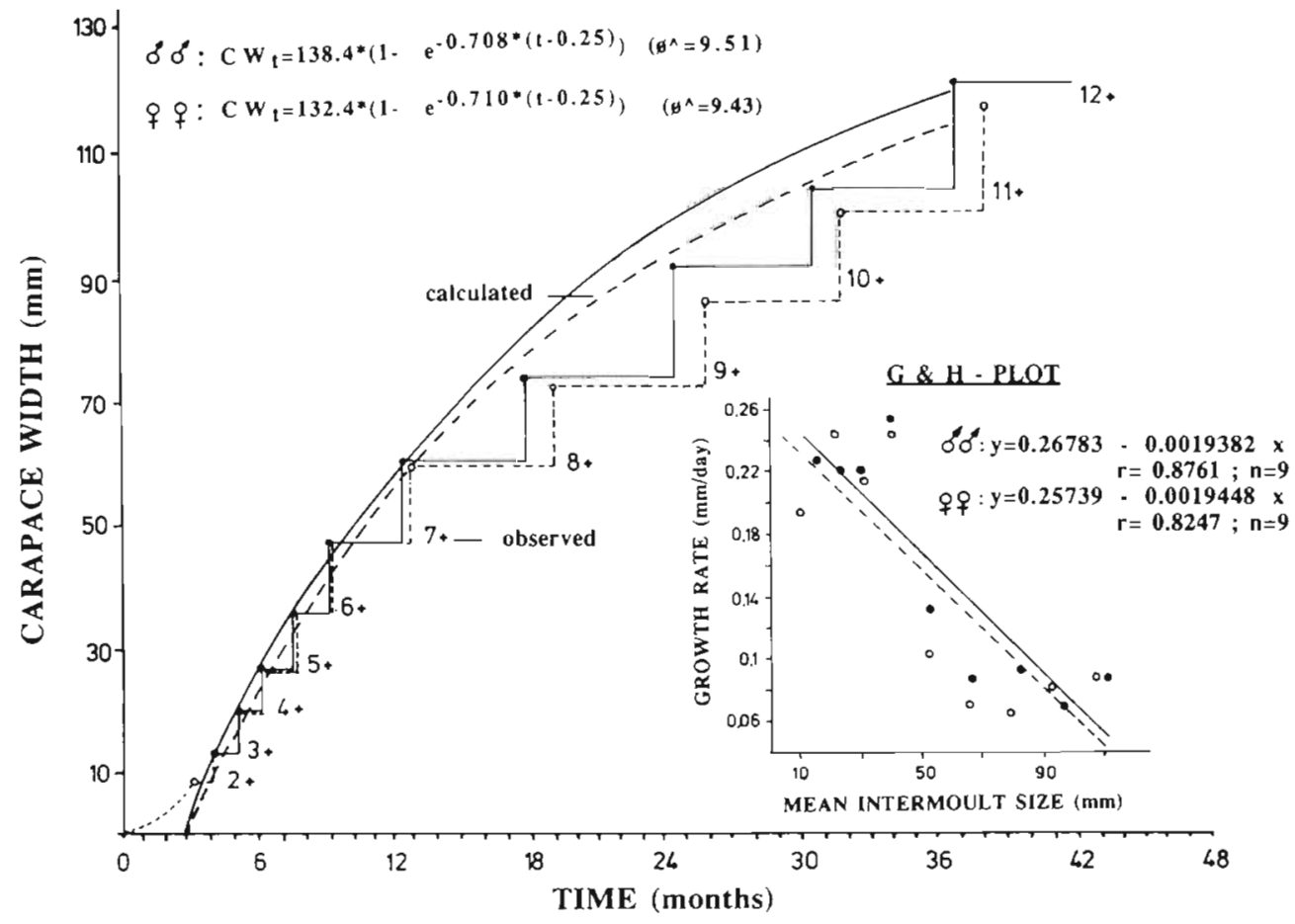

was found to better approximate the post-moult/premoult relationship than a single-line model, as the residual sum of squares was significantly lower for the former compared to the latter model (Table 1). The inflection point of both lines lies between instars $7+$ and $8+$, coinciding with the size where absolute growth dropped markedly (Fig. 3).

\section{Field growth}

Absolute growth. The original length frequencies used as input for the ELEFAN I programm are seen in Fig. 5, together with the von Bertalanffy growth curves and the corresponding parameter estimates.

Growth per moult. Fig. 6 shows the $C W$ histograms of the pooled data of male and female specimens and the normally distributed components (instars) that were detected using the Bhattacharya method. The instar sizes of both field and laboratory specimens are presented as a 'Hiatt diagram' in Fig. 4.

\section{Size at first maturity $\left(C W_{\mathrm{m}}\right)$}

$C W_{\mathrm{m}}$ was found to be in the range 97.1 to $99.1 \mathrm{~mm}$ in females and 123.1 to $124.8 \mathrm{~mm}$ in males (Table 2, Fig. 2). These sizes correspond to ca 1.9 and 2.1 yr of age respectively. The smallest egg-carrying female found in the study measured only $67 \mathrm{~mm} \mathrm{CW}$, indicating that some females might well mature earlier in life. The same seems to hold true for males as some individuals of sizes below $C W_{\mathrm{m}}$ already exhibit large-sized chelae, characteristic for maturity (Fig. 2, left upper line).

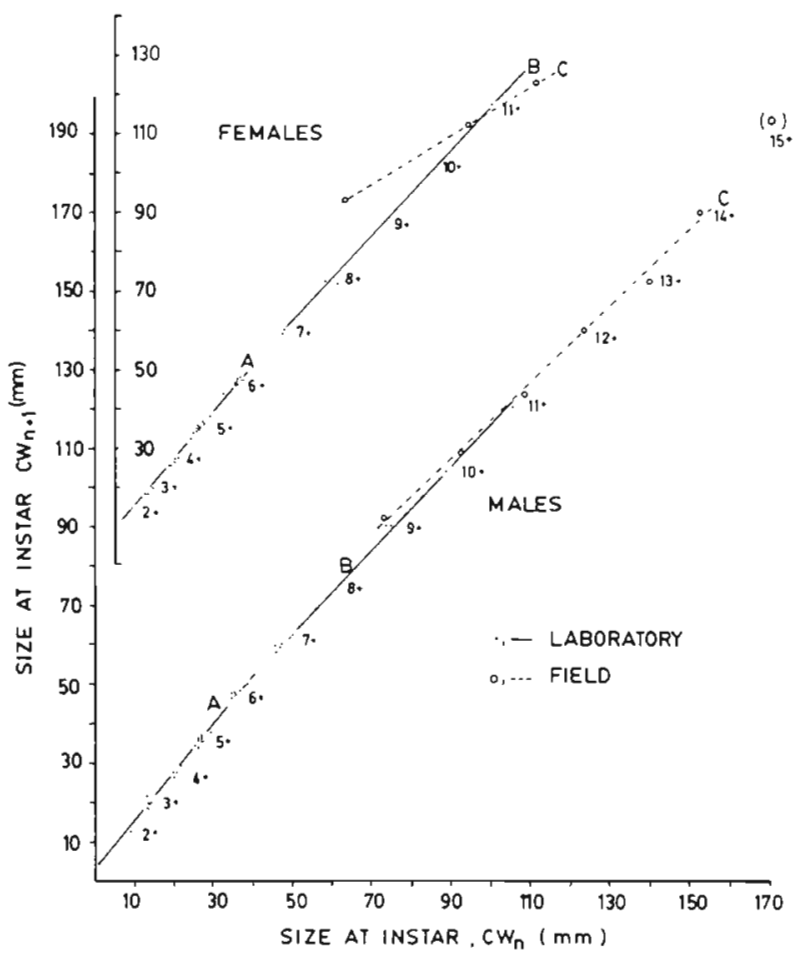

Fig. 4. Cancer polyodon. Hiatt diagram for laboratory-held (lines A, B) and field (line C) specimens (sizes correspond to instar numbers to be read from horizontal axis; for regression equations see Table 1) 
Table 1. Regression equations for Hiatt diagrams presented in Fig. $4\left(y=C W_{n+1}, x=C W_{n}\right)$

\begin{tabular}{|c|c|c|c|c|c|}
\hline Line & Equation & $\mathrm{r}$ & $\mathrm{n}$ & RSS & $F$ \\
\hline \multicolumn{6}{|c|}{ Females } \\
\hline A & $y=3.186+1.210 x$ & 0.9949 & 22 & 11.45 & \multirow{5}{*}{$18.61^{\circ}$} \\
\hline $\mathrm{B}$ & $y=8.660+1.074 x$ & 0.9985 & 19 & 24.84 & \\
\hline Sum & & & & 36.29 & \\
\hline$A+B$ & $y=5.452+1.127 x$ & 0.9983 & 41 & 71.84 & \\
\hline C & $y=56.00+0.595 x$ & 0.9997 & 3 & - & \\
\hline \multicolumn{6}{|c|}{ Males } \\
\hline A & $y=3.364+1.212 x$ & 0.9898 & 23 & 22.57 & \multirow{5}{*}{$24.01^{\circ}$} \\
\hline B & $y=9.859+1.063 x$ & 0.9990 & 18 & 18.60 & \\
\hline Sum & & & & 41.67 & \\
\hline$A+B$ & $y=5.990+1.120 x$ & 0.9981 & 41 & 93.20 & \\
\hline $\mathrm{C}$ & $y=20.92+0.957 x$ & 0.9945 & 6 & - & \\
\hline
\end{tabular}

\section{Spawning}

Spawning probably occurred during the whole year as females with mature eggs were found in all months (Fig. 7). The percentage of females with mature eggs, however, was highest during winter (July and August) and summer (November to Janu- ary), indicating 2 major spawning pulses during these periods.

\section{Total mortality $(Z)$ and natural mortality $(M)$}

The instantaneous rate of total mortality $(Z)$ as estimated from the catch curve was higher for males than

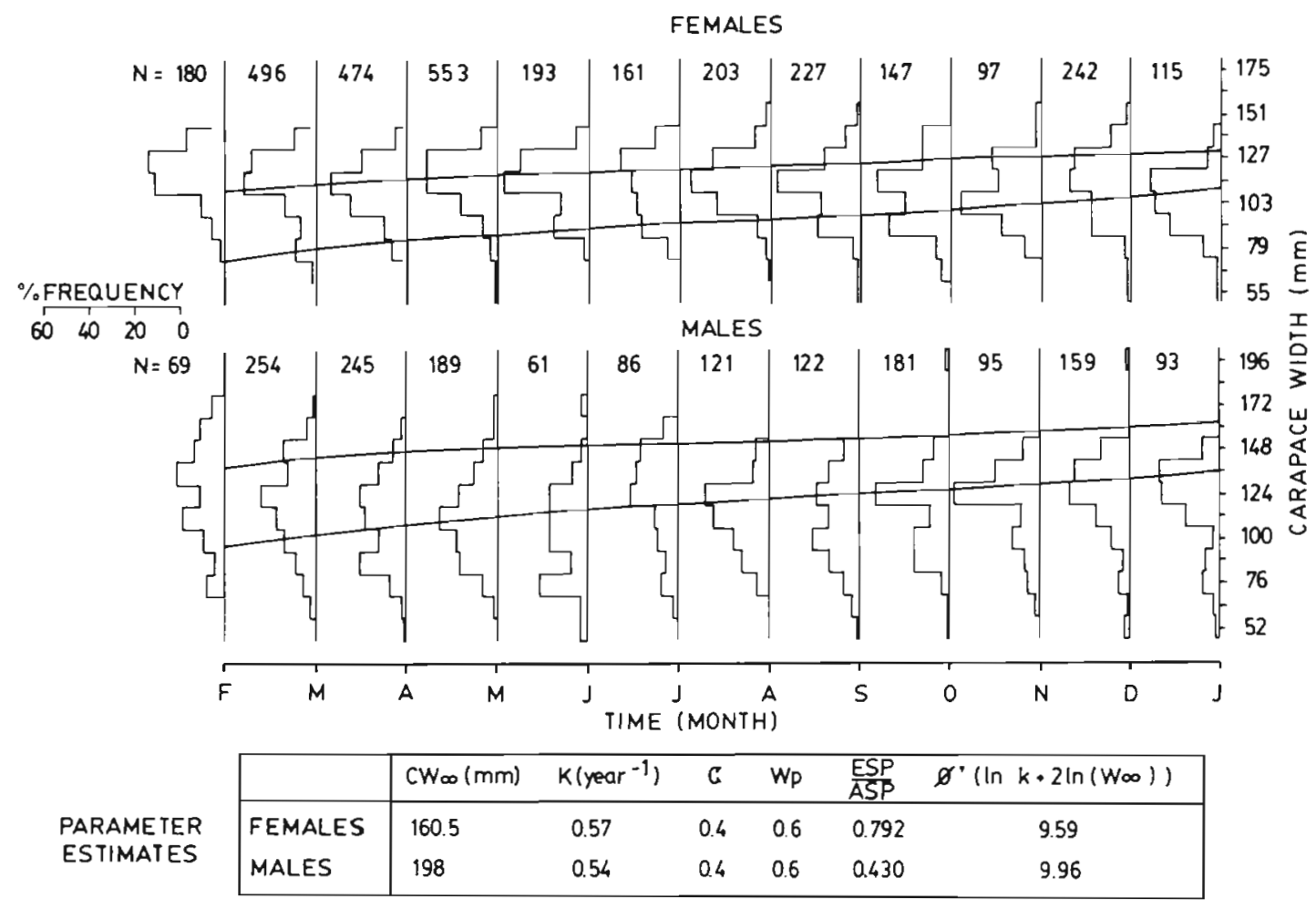

Fig. 5. Cancer polyodon. Absolute growth in the natural habitat as derived from ELEFAN analysis. CW $W_{\infty} k$ : von Bertalanffy growth parameters; $C$ : constant of growth oscillation; Wp: time of the year when growth is lowest; ESP/ASP: goodness of fit criteria of the ELEFAN program; $\phi^{\prime}$ : growth performance index 


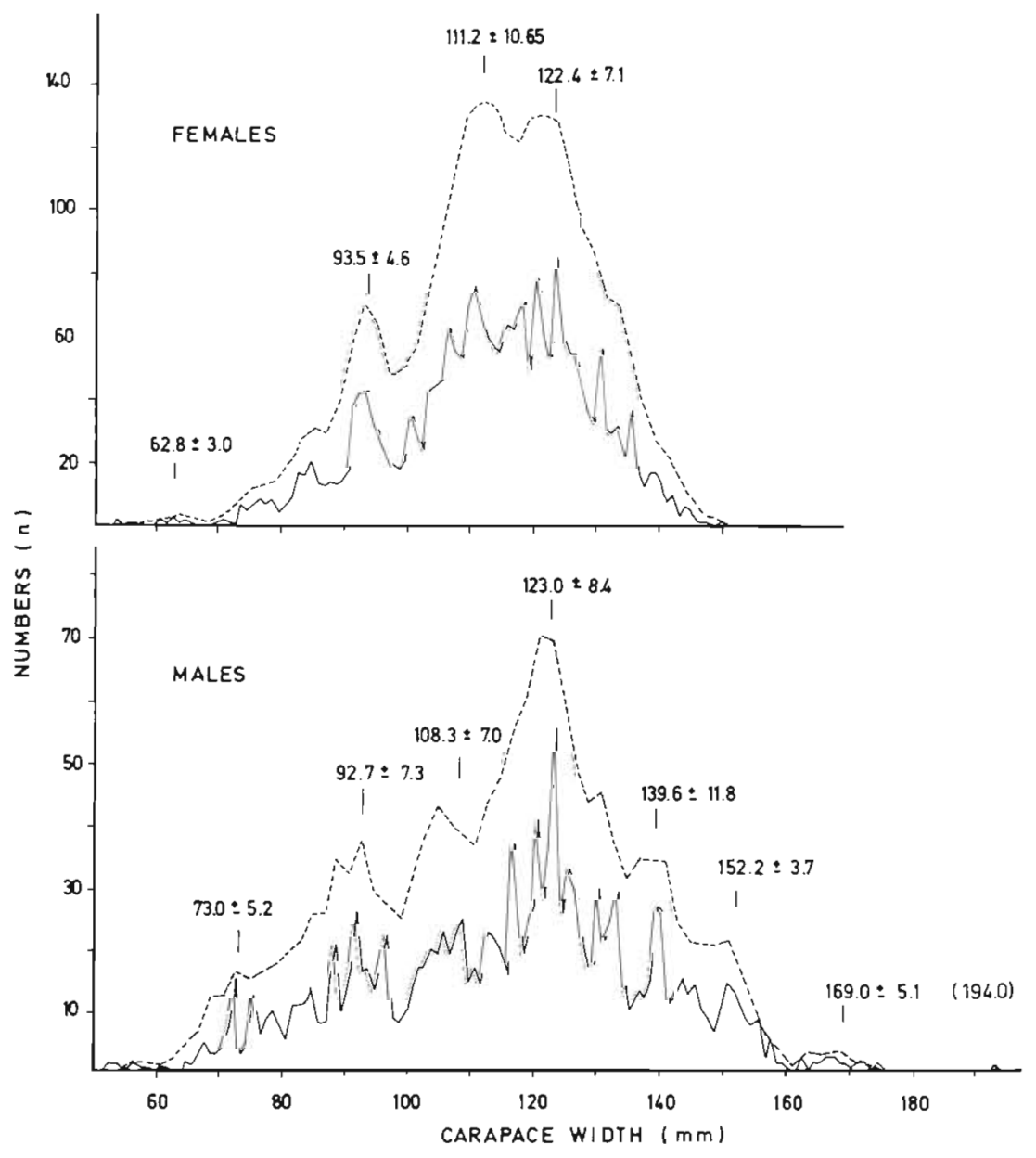

Fig. 6. Cancer polyodon. Total catch of females and males. (....) $2 \mathrm{~mm}$ intervals smoothed by a running average over 3 intervals; (-) $1 \mathrm{~mm}$ interval; numbers correpond to size of instars

for females (2.56 compared to 1.85) (Fig. 8). The cohort analysis (Table 3 ) as well as the good fit of the quadratic regression to the catch curve data (Fig. 8)

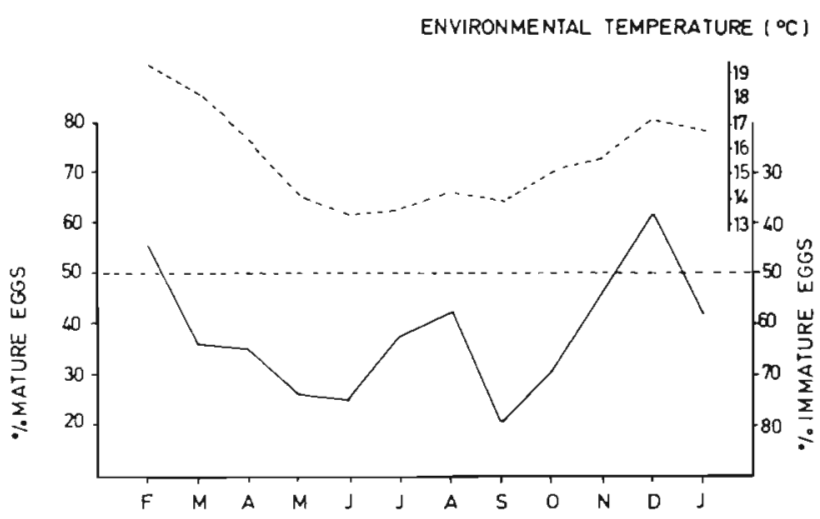

Fig. 7. Cancer polyodon. Proportion of mature and immature eggs of females and environmental temperature during the study period indicate a general increase of $Z$ with size for both sexes. Exploitation was heavy above $110 \mathrm{~mm}$ $C W$. Based on the age of first massive maturity, natural mortality was estimated as 0.80 and 0.74 for females and males respectively. Inserting the growth parameters calculated in this study and the mean annual water temperature of ca $14.5{ }^{\circ} \mathrm{C}$ into Pauly's formula resulted in $M$-values of 1.00 for females and 0.99 for males

\section{Population structure, mean annual biomass and density estimates}

The mean annual biomass of lemales was 2.4 times greater than that of males ( 378 to $525 \mathrm{~kg}$ compared to 166 to $204 \mathrm{~kg}$ for the range of $M$-values used; Table 3 ). The size range of the captured specimens was different for both sexes. Females were caught from sizes of $55 \mathrm{~mm} \mathrm{CW}$ onwards, while the smallest male measured $76 \mathrm{~mm} \mathrm{CW}$; the last length group that contributed a significant number of male specimens was 166 to $172 \mathrm{~mm}$ compared with 139 to $145 \mathrm{~mm}$ in females. Exploitation was more intense for males than females over all intervals. Despite the large difference in total and spawning biomass between sexes, the yield of females was only $36 \%$ higher than that of males, mainly due to higher average sizes and weights of males. The comparison of the pooled trap catches with the pooled diver catches did not show any significant differences (Fig. 9), indicating that the trap catches can be considered representative for the population structure in the study area. The monthly catches varied during the year in a similar way for females and males, being highest during the mid to late summer months (February to April) (Fig. 10). Thereafter they dropped markedly in May and increased slightly until August (females) and September (males) before reaching a second minimum in October.

The average density in the 4 transects of a total area of $600 \mathrm{~m}^{2}$ was 0.15 ind. $\mathrm{m}^{-2}$ (53.4 $\mathrm{g}$ fresh weight $\mathrm{m}^{-2}$ ). Average sex ratio (female:males) over the 4 transects was $2.3: 1$ (range from $1.5: 1$ to $3.0: 1$ ). 
Table 2. Cancer polyodon. Size at massive maturity $\left(C W_{m}\right)$ for males and females and its calculation by the method of Udupa (1986). $M L_{l}=$ midlength of size-group $i_{i} N_{i}=$ total no. in size-group $i_{i} M_{i}=$ no. of mature specimens in size-group $i_{i} P_{i}=M_{i} / N_{i}$

\begin{tabular}{|c|c|c|c|c|c|c|c|}
\hline$M L_{j}$ & $\ln M L_{1}$ & $N_{1}$ & $M_{i}$ & $P_{i}$ & $\ln M L_{i+1}-\ln M_{i}$ & $1-P_{i}$ & $P_{1} \frac{1-P_{i}}{N_{i}-1}$ \\
\hline \multicolumn{8}{|l|}{ Females } \\
\hline 83.5 & 4.4248 & 6 & 1 & 0.17 & 0.0353 & 0.83 & 0.0282 \\
\hline 86.5 & 4.4601 & 6 & 1 & 0.17 & 0.0341 & 0.83 & 0.0282 \\
\hline 89.5 & 4.4942 & 5 & 1 & 0.21 & 0.0330 & 0.80 & 0.0400 \\
\hline 92.5 & 4.5272 & 13 & 4 & 0.31 & 0.0319 & 0.69 & 0.0178 \\
\hline 95.5 & 4.5591 & 7 & 3 & 0.43 & 0.0310 & 0.57 & 0.0409 \\
\hline 98.5 & 4.5901 & 6 & 3 & 0.50 & 0.0300 & 0.50 & 0.0500 \\
\hline 101.5 & 4.6201 & 11 & 7 & 0.64 & 0.0291 & 0.36 & 0.0230 \\
\hline 104.5 & 4.6492 & 10 & 7 & 0.70 & 0.0283 & 0.30 & 0.0233 \\
\hline 107.5 & 4.6775 & 19 & 16 & 0.84 & 0.0275 & 0.16 & 0.0075 \\
\hline 110.5 & 4.7050 & 7 & 6 & 0.85 & 0.0268 & 0.15 & 0.0213 \\
\hline 113.5 & 4.7318 & 9 & 8 & 0.89 & 0.0261 & 0.11 & 0.0122 \\
\hline 116.5 & 4.7579 & 8 & 7 & 0.88 & 0.0254 & 0.12 & 0.0151 \\
\hline 119.5 & 4.7833 & 11 & 10 & 0.91 & 0.0248 & 0.09 & 0.0082 \\
\hline 122.5 & 4.8081 & 12 & 11 & 0.92 & 0.0242 & 0.08 & 0.0067 \\
\hline 125.5 & 4.8323 & 2 & 1 & 0.50 & 0.0236 & 0.50 & 0.2500 \\
\hline 128.5 & $4.8559^{\circ}$ & 2 & 2 & 1.00 & - & 0.00 & - \\
\hline Sum & & 134 & 88 & 9.91 & $0.0287^{b}$ & 6.09 & 0.5724 \\
\hline \multicolumn{8}{|l|}{ Males } \\
\hline 116.5 & 4.7579 & 29 & 1 & 0.03 & 0.0085 & 0.97 & 0.0010 \\
\hline 117.5 & 4.7664 & 25 & 8 & 0.32 & 0.0085 & 0.68 & 0.0091 \\
\hline 118.5 & 4.7749 & 12 & 4 & 0.33 & 0.0084 & 0.67 & 0.0201 \\
\hline 119.5 & 4.7833 & 21 & 1 & 0.05 & 0.0083 & 0.95 & 0.0024 \\
\hline 120.5 & 4.7916 & 24 & 4 & 0.17 & 0.0083 & 0.83 & 0.0061 \\
\hline 121.5 & 4.7999 & 21 & 10 & 0.48 & 0.0082 & 0.52 & 0.0124 \\
\hline 122.5 & 4.8081 & 26 & 14 & 0.54 & 0.0081 & 0.46 & 0.0099 \\
\hline 123.5 & 4.8162 & 42 & 30 & 0.71 & 0.0081 & 0.29 & 0.0050 \\
\hline 124.5 & 4.8243 & 17 & 12 & 0.71 & 0.0080 & 0.29 & 0.0129 \\
\hline 125.5 & 4.8323 & 21 & 8 & 0.38 & 0.0079 & 0.62 & 0.0118 \\
\hline 126.5 & 4.8402 & 17 & 12 & 0.71 & 0.0079 & 0.29 & 0.0129 \\
\hline 127.5 & 4.8481 & 10 & 6 & 0.61 & 0.0078 & 0.40 & 0.0267 \\
\hline 128.5 & 4.8559 & 9 & 4 & 0.48 & 0.0078 & 0.52 & 0.0312 \\
\hline 129.5 & 4.8637 & 10 & 5 & 0.50 & 0.0077 & 0.50 & 0.0278 \\
\hline 130.5 & 4.8714 & 16 & 15 & 0.94 & 0.0076 & 0.06 & 0.0038 \\
\hline 131.5 & 4.8790 & 9 & 8 & 0.89 & 0.0076 & 0.11 & 0.0122 \\
\hline 132.5 & $4.8866^{\mathrm{a}}$ & 13 & 13 & 1.00 & - & 0.00 & - \\
\hline Sum & & 322 & 155 & 8.84 & $0.0080^{b}$ & 8.16 & 0.2054 \\
\hline \multicolumn{2}{|c|}{ Calculation procedure: } & \multicolumn{6}{|c|}{$\begin{array}{l}\ln C W_{\mathrm{m}}=X_{k}+X / 2-\sum P_{i} \\
\text { where } X_{k}=\ln \text { size at which } 100 \% \text { of specimens are mature }\left({ }^{a}\right) ; X=\text { average ln size increment }\left({ }^{b}\right) \text {. }\end{array}$} \\
\hline Results: & $\begin{array}{l}\text { Females: } \\
\text { Males: }\end{array}$ & \multicolumn{6}{|c|}{$\begin{array}{l}C W_{\mathrm{m}}=98.09(\mathrm{CI}: 97.05 \text { to } 99.13) \\
C W_{\mathrm{m}}=123.95(\mathrm{CI}: 123.09 \text { to } 124.81)\end{array}$} \\
\hline
\end{tabular}

\section{DISCUSSION}

\section{Growth, biometric relationships and size at massive maturity}

The difference found in weight and asymptotic size for females and males of Cancer polyodon is a commonly reported feature of brachyuran crabs [Krouse (1972, 1976) for Cancer irrotatus; Donaldson et al.
(1981) for Chionoecetes bairdi; Gonzalez Gurriaran (1985) for Macropipus puber; Orensanz \& Galucci (1988) for Cancer magister, Cancer gracilis and Cancer productus; Wenner \& Stokes (1984) for Menippe mercenaria]. The similar growth found for immature specimens of both sexes in the laboratory (Fig. 3) has also been described for the brachyuran crabs in the abovecited reports. According to the von Bertalanffy growth curves calculated for laboratory-reared and wild spec- 
imens, the former grew with a higher instantaneous growth rate (higher $k$ value) but approached a smaller asymptotic size $\left(C W_{\infty}\right)$ compared to the latter (Figs. $3 \& 5$ ). The higher growth rate could be attributed to more favourable food conditions in the laboratory (higher amounts and digestability of food, as only shellfree meat was supplied) and to the avoidance of energy expenditure for territorial behaviour and cannibalism. The smaller asymptotic size could indicate that space was growth limiting for larger specimens. We think that the simple and most widely used von Bertalanffy model reasonably describes the growth of C. polyodon (at least for the later juvenile and adult phases) because of the following: (1) visual inspection of the growth curves passing through the frequency histograms showed a reasonable fit (Fig. 5); (2) the ELEFAN analysis yielded $C W_{\infty}$-values for males and females of $198.0 \mathrm{~mm}$ and $160.5 \mathrm{~mm}$ respectively, near to the maximum sizes found in this study of $194.5 \mathrm{~mm}$ for males and $151 \mathrm{~mm}$ for females; (3) the growth oscillation found $(C=0.4)$ was consistent with the relationship with annual temperature found by Pauly (1984) for shrimps and fish and findings for other invertebrates of the same latitude, such as the scallop Argopecten purpuratus (Etchepare et al, 1989) and the sea urchin Tetrapygus niger (Stotz pers. comm.).

Male and female Cancer polyodon moult on an average 7 times during the first year, 3 during the second and 2 during the third year of life (Figs. 4, $5 \& 6$ ). The terminal moult seems to be $16+$ in males and $14+$ in

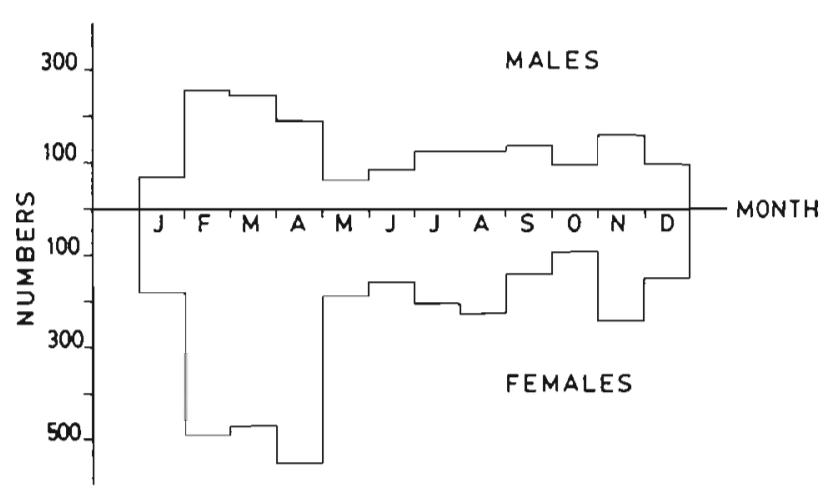

Fig. 9. Cancer polyodon. Size frequency of trap and diver catches females. Gutierrez \& Zuniga (1976) reported only 15 instars for males of the same species. As the percentage of specimens of instar $16+$ was very low in the present study ( 2 out of 1633), it is probable that the above authors did not find such large specimens during their study. Orensanz \& Galucci (1988) found lower instar numbers for C. magister (13), C. oregonensis (11), C. productus (13) and C. gracilis (12) but cited reports of 16 instars for C. magister (Poole 1967, Collier 1983). Gonzales Gurriaran (1985) and Melville-Smith (1989) reported instar numbers of 17 for Macropipus puber and 16 for Geryon maritae. This indicates that instar

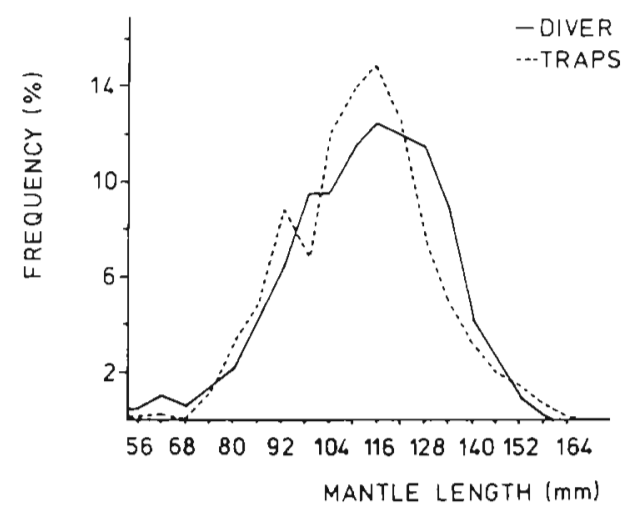

Fig. 10. Cancer polyodon. Monthly catches of females and males 


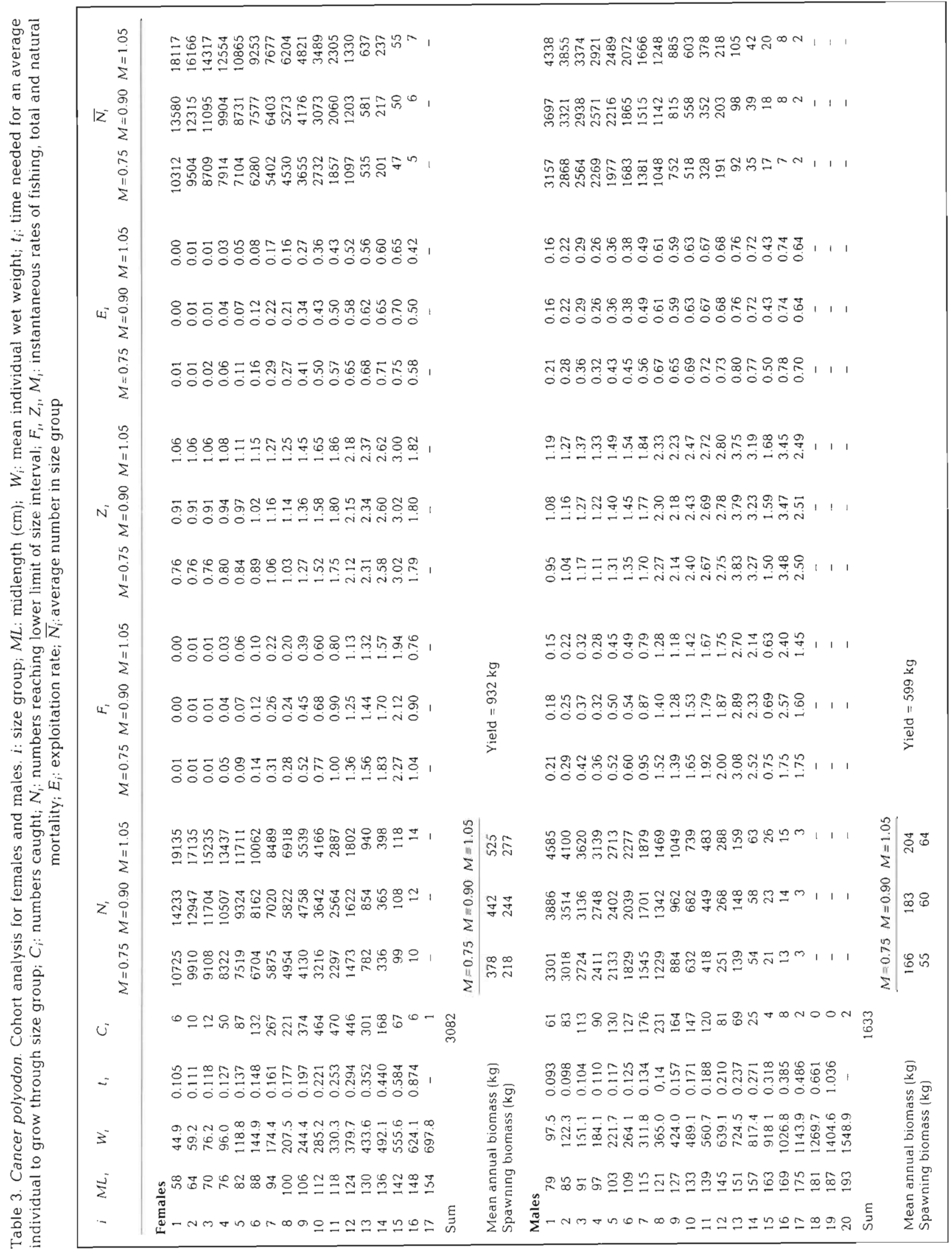


number may vary between species of brachyuran crabs.

The reduction of the absolute growth rate by about $50 \%$ in both sexes of Cancer polyodon from instar $7+$ to $8+$ (Fig. 3) coincides with the intersection of the 2 fitted lines describing the premoult-postmoult relationship (Fig. 4). Donaldson et al. (1981) found a similar inflection point in the Hiatt diagram for $C$. bairdi within the same size range and attributed it to a change in lifestyle, i.e migration to deeper waters Perhaps the abrupt change in absolute growth in $C$. polyodon and the 'change in lifestyle' of $C$. bairdi are associated with a metabolic (hormonal) change marking the onset of gonad formation. The abovementioned authors substantiate this, as they report a long time span (ca $2 \mathrm{yr}$ ) between ovary formation and appearance of orange ova in $C$. bairdi. While most female specimens of $C$. polyodon mature at instar $11+$ (or $10+)$ and most males at instar $12+$, some individuals seem to mature earlier. The smallest egg-carrying female measured only $67 \mathrm{~mm}$ and some males of little more than $70 \mathrm{~mm} \mathrm{CW}$ had very big chelae, indicating maturity (Fig. 2).

Larger size at maturity, greater robustness, bigger chelae and larger size of males, as well as the predominance of females over most of the study period (Fig. 10) suggest a polygynous mating system in which one male might occupy and defend a group of females. This has been reported for species of Cancer by Cleaver (1949), Butler (1960), Snow \& Neilson (1966) and Orensanz \& Galucci (1988).

\section{Spawning}

Spawning peaked during July/August and November/December (Fig. 7) which coincides well with the observations of Gutierrez \& Zuniga (1976) for the same species at Mejillones, about $800 \mathrm{~km}$ to the north of La Herradura Bay. They also found less intense spawning in winter (July to September) and a more intense spawning during the summer (January to April)

\section{Mortality}

Total mortality of both sexes $(Z=2.6$ and 1.85 for males and females respectively) was low when compared with the calculated Z-value (9.2) for the heavily exploited Dungeness crab Cancer magister in British Columbia, Canada (Smith \& Jamieson 1989). Gonzalez Gurriaran (1985) estimated $Z$-values of 1.53 for males and 1.79 for females for the commercially exploited crab Macropipus puber in Galicia, Spain, which are close to our values. As seen from the cohort analysis (Table 3), and from Fig. 8, the $Z$-values tend to increase with size in both sexes. This could be due to either increasing fishing and/or higher natural mortality with age. Orensanz \& Galluci (1988) found dead and moribund $C$. productus, $C$. gracilis and C. magister in the field and think that senescence might be the most important source of adult mortality in these species. Hankin et al. (1985) also observed increased mortality with age in female $C$. magister and attributed this partly to senescence with concomitant shell deterioration. Hill (1975) reported an increase in mortality from the second to third year of the portunid crab Scylla serrata. Our diving observations did not give evidence, however, that senescence is an important source for natural mortality in C. polyodon as moribund individuals of older ages were not found. Smith \& Jamieson (1989) suggest that natural mortality might increase in C. magister as intermoult period increases. They demonstrated that a quadratic regression fitted the data of the catch curve slightly better than a linear regression coinciding with our results (Fig. 8). Fishing mortality could also have increased with size of $C$. polyodon, if the catchability of larger crabs is higher. Larger crabs can presumably walk faster and travel longer distances and therefore might have competitive advantages over smaller crabs when entering the trap. Diving observations suggest that larger crabs are better retained in traps because of their size and inferior swimming capacity. Our estimates for the instantaneous rates of natural mortality $(M)$ were similar for both sexes but differed according to the method employed. Rikhter \& Evanov's formula yielded lower $M$ values (by 20 to $25 \%$ ) than Pauly's formula. As both formulas employed were considered to yield only rough estimates for $M$, it seemed advisable to use an envelope of $M$-values for the cohort analysis (Table 3 ).

\section{Population structure, mean annual biomass and density}

The maximum biomass of males is near the size at massive maturity and displaced to the right of the size at massive maturity in females (Fig. 6). This suggests that natural selection favours offspring production over biomass maximization in females and coincides with the fact that females in general are smaller and less robust than males. The wide confidence intervals for the size-at-instar, as obtained from the Bhattacharya analysis (Fig. 6), indicate individual variability probably due to environmental heterogeneity or genetic variation

During September and October, the catch was lowest (Fig. 10), possibly due to migration of females (and 
males?) or burying into the sand after moulting. In these months the sex ratio approached $1: 1$, whereas it was 2 to 3 females per male during the rest of the year. Crabs $<55 \mathrm{~mm} C W$ were not caught in the study area (depth range ca 4 to $10 \mathrm{~m}$ ), either by the traps or by the diver (Fig. 9). The smaller specimens used for the laboratory experiments (Fig. 3) had to be collected between rocks in the intertidal area. It thus appears that the megalopa larvae settle in this area and do not successfully invade the deeper sandy bottom area until they reach at least $55 \mathrm{~mm} \mathrm{CW}$. A very high proportion of small crabs in the stomachs of older individuals (Cerda \& Wolff unpubl.) indicates strong cannibalism of smaller by larger crabs. The average crab density and biomass of 0.15 individuals or $53.4 \mathrm{~g} \mathrm{~m}^{-2}$ on a total area of $600 \mathrm{~m}^{2}$ found in May can be considered as a low limit estimate as May was a month of low captures (Fig. 10). Assuming proportionality to catches, density should have ranged between 0.15 and 0.5 crabs $\mathrm{m}^{-2}$. As mean biomass for both sexes in the area effectively fished by the traps was estimated as 544 to $729 \mathrm{~kg}$ (Table 3 ), the extent of this area can roughly be estimated as $5964 \mathrm{~m}^{2}$ (taking 0.3 crabs $\mathrm{m}^{-2}$ and $637 \mathrm{~kg}$ as average density and biomass values).

Based on the $Z$-values estimated in this study, annual biomass production was thus about $1317 \mathrm{~kg} / 5964 \mathrm{~m}^{2}$ or $221 \mathrm{~g}$ crab biomass $\mathrm{m}^{-2}$. Our density estimates are higher than those reported by Orensanz \& Galucci (1988) for C. gracilis $(0.026$ to 0.096 as an average and $0.4 \mathrm{crabs} \mathrm{m}^{-2}$ in exceptionally dense aggregates) and Gonzalez Gurriaran (1985) for Macropipus puber $\left(0.0008\right.$ to $0.08 \mathrm{crabs}^{-2}$ corresponding to 0.02 to $2.02 \mathrm{~g}$ fresh weight $\mathrm{m}^{-2}$ ).

The high biomass, density and production of Cancer polyodon in the study area suggest favourable food conditions (high densities and productivities of prey species).

Acknowledgements. This study received financial support by project D.G.I. Universidad Catolica del Norte \#68.71. Our sincere thanks go to M.Sc. Rachel Wolff and to 4 unknown referees, whose critical reading and suggestions helped to improve the manuscript.

\section{LITERATURE CITED}

Augsburger, A., Vega, R. (1989). Transferencia de semillas del recurso ostion (Arpopecten purpuratus) al medio natural. In: Estudio repoblamiento de recursos bentonicos área piloto IV Region, II. Investigatiónes específicas. Corp. de Fomento de la Produccion y Instituto de Fomento Pesquero, Santiago, Ap 89/3b, p. 143-181

Bhattacharya, C. G. (1967). A simple method of resolution of a distribution into Gaussian components. Biometrics 23: $115-135$

Butler, T. H. (1960). Maturity and breeding of the Pacific edible crab. Cancer magister Dana. J. Fish. Res. Bd Can. 18: $873-891$
Cleaver, F. C. (1949). Preliminary results of the coastal crab (Cancer magister) investigation. Wash. Dep. Fish. Biol. Rep. 49A: $47-82$

Collier, P. C. (1983). Movement and growth of postlarval Dungeness crabs Cancer magister, in the San Francisco area. In: Wild, P. W., Tasto, R. N. (eds.) Life history, environment and mariculture studies of the Dungeness crab, Cancer magister, with emphasis on the Central California fishery resource. Fish Bull. (Calif.) 172: 125-133

DiSalvo, L. H., Alarcon, E., Matrinez, E., Uribe, E. (1984). Progress in mass culture of Argopecten purpuratus with notes on its natural history. Revta chil. Hist. nat. 57: 33-45

Donaldson, W. E, Cooney, R. T., Hilsinger, J. R. (1981). Growth, age and size at maturity of Tanner crab, Chionoecetes bairdi M. J. Rathburn, in the Northern Gulf of Alaska (Decapoda, Brachyura). Crustaceana 40: $287-302$

Etchepare, I., Videla, V., Canas, P., Lozada, E., Pacheco, E., Carmona, A., Schufeneger, M., Iduya, C. (1989). Estudios ecológicos. In: Estudio repoblamiento de recursos bentonicos área piloto IV Region, II. Investigaciónes específicas. Corp. de Fomento de la Produccion y Instituto de Fomento Pesquero, Santiago, Ap 89/3b, p. 185-276

Garth, J. (1959). Reports of the Lund University Chile expedition 1948-1949. The Crustacea Decapoda Brachyura of Chile. Lunds Univ. Arsskr. 53(7): 1-130

Gonzalez Gurriaran, E. (1985). Crecimiento de la necora (Macropipus puber (L.)) (Decapoda, Brachyura) en la Ría de Arousa (Galicia, NW Espana), y primeros datos sobre la dinámica dela población. Boln Inst. esp. Oceanogr. 2: $33-51$

Gulland, J. A., Holt, S. L. (1959). Estimation of growth parameters for data at unequal time intervals. J. Cons. perm. int. Explor. Mer 25: 47-49

Gutierrez, J., Zuniga, O. (1976). Cancer setosus Molina en la Bahia de Mejillones del Sur. (Crustacea, Decapoda, Brachyura). Revta Biol. mar. 16: 1-28

Hankin, D. G., Diamond, N., Mohr, M., Ianelli, J. (1985). Molt increments, annual moulting probabilities, fecundity and survival rates of adult female Dungeness crabs in Northern California. In: Melteff, B. R. (ed.) Proceedings of the symposium on Dungeness crab biology and management. Univ. of Alaska, Alaska Sea Grant Rep. No. 85-3, p. $189-208$

Hiatt, R. W. (1948). The biology of the lined shore crab Pachyrapsus crassipes Randall. Pacif. Sci. 2: 135-213

Hill, B. J. (1975). Abundance, breeding and growth of the crab Scylla serrata in two South African estuaries. Mar. Biol. 32: $119-126$

Jones, R. (1984). Assessing the effects of changes in exploration pattern and length composition data (with notes on VPA and cohort analysis). F.A.O. Fish. tech. Pap. 256

Krouse, J. S. (1972). Some life history aspects of the rock crab, Cancer irroratus, in the Gulf of Maine. J. Fish. Res. Bd Can. 29: 1479-1482

Krouse, J. S. (1976). Size composition and growth of young rock crab. Cancer irroratus, on a rocky beach. Fish. Bull. U.S. 77: $949-954$

Melville-Smith, R. (1989). A growth model for the deep sea crab (Geryonmantae) off Southwest Africa/Namibia (Decapoda, Brachyura). Crustaceana 56: 279-292

Mendo, J., Valdivieso, V., Yamashiro, C., Jurado, E., Moron, O., Rubio, J. (1987). Evaluacion de la concha de abanico (Argopecten purpuratus) en la Bahia de Independencia, Pisco, Peru, 17 de Enero-4 de Febrero de 1987. Instituto del Mar del Peru (IMARPE), Callao, Informe 91: $1-64$ 
Orensanz, J. M., Galucci, V. H. (1988). Comparative study of postlarval life-history schedules in four symatric species of Cancer (Decapoda: Brachyura: Cancridae). J. Crust. Biol. 8: $187-220$

Pauly, D. (1980). On the interrelationship between natural mortality, growth parameters and mean environmental temperature in 175 fish stocks. J. Cons. int. Explor. Mer 36: $175-192$

Pauly, D. (1984). Fish population dynamics in tropical waters: a manual for use with programmable calculators. International Center for Living Aquatic Resources Management (ICLARM), Manila, Studies and Reviews 8

Pauly, D. (1985). A review of the ELEFAN system for analysis of length frequency data in fish and aquatic invertebrates. International Council for Living Aquatic Resources Management (ICLARM), Manila, Contribution 232

Pauly, D., Gaschuetz, G. (1979). A simple method for fitting oscillating length growth data, with a program for pocket calculators. Comm. Meet. int. Coun. Explor. Sea C.M.ICES/G 24: 1-26

Pauly, D., Munro, J. L. (1984). Once more on the comparison of growth in fish and invertebrates. Fishbyte 2: 21

Poole, R. L. (1967). Preliminary results of the age and growth study of the market crab (Cancer magister) in Bodega Bay. Proc. Symp. Crustacea 1965, Ernakulam, Mar. Biol. Ass. India 2: 553-567

Quintana, R. (1981). Desarrollo larval de tres especies de Cancridae bajo condiciones de laboratorio (Decapoda, Brachyura). Tesis Univ, de Concepcion (Chile)

Rikhter, V. A., Efanov, V. N. (1976). On one of the approaches

This article was presented by $J$. Winter, Valdivia, Chile to estimation of natural mortality of fish populations. Int. Commn NW Atl. Fish. Res. Doc. 76/VI/8: 1-12

SERNAP (1980-1987). Annuario estatistico de pesca. Servicio Nacional de Pesca. Ministerio de Economica, Fomento y Reconstruccion, Santiago, Chile

Smith, B. D., Jamieson, C. S. (1989). Exploitation and mortality of male Dungeness crabs (Cancer magister) near Tofino, British Columbia. Can. J Fish. Aquat. Sci. 46: 1609-1614

Snow, C. D., Neilson, J. R. (1966). Premating and mating behavior of the Dungeness crab (Cancer magister). J. Fish. Res. Bd Can. 23: 1319-1323

Somerton, D. A. (1980). A computer technique for estimating the size of sexual maturity in crabs. Can. J. Fish. Aquat. Sci. 37: 1488-1494

Sparre, P. (1987). Computer programs for fish stock assessment for Apple II computers. F.A.O. Fish. tech. Pap. 101 Suppl. 2: 1-218

Talledo, C., Ishiyama, V. (1988). Reproductive cycle of the female Cancer setosus from the littoral of Lima, Peru. In: Salzwedel, H., Landa, A. (eds.) Recursos y dinamica del ecosistema de afloramienta peruano. Bol. Inst. Mar. PeruCallao, Vol. extraordinario: 1-382

Udupa, K. S. (1986). Statistical method for estimating the size at first maturity in fishes. Fishbyte 4: 8-10

Wenner, E. L., Stokes, A. D. (1984). Observations on the fishable population of the stone crab Menippe mercenaria (Say) in South Carolina waters. J. Shellfish Res. 4: 145-153

Wolff, M. (1987). Population dynamics of the Peruvian scallop Argopecten purpuratus during the El Niño phenomenon of 1983. Can. J. Fish. Aquat. Sci. 44: 1684--1691

Manuscript first received: February 1, 1992

Revised version accepted: June 24, 1992 